\title{
Study on localization of sudanophilia in mandibular condyles of rats given strontium carbonate
}

\author{
Masaru Nagayama, Tohru Oka, Shoji Yamada* and Akira Matsumoto* \\ Department of Oral Surgery (Chief: Prof. Tohru Oka), School of Medicine, Nagoya University, \\ 65, Tsuruma-cho, Showa-ku, Nagoya 466, Japan \\ *Department of Dental Pharmacology (Chief: Prof. Akira Matsumoto), School of Dentistry, \\ Showa University, 1-5-8, Hatanodai, Shinagawa-ku, Tokyo 142, Japan
}

[Accepted for publication: June 14, 1984]

Key words: sudanophilia / mandibular condyle / calcification/lipid/strontium carbonate

\section{Introduction}

The mechanism of ossification in bone is not clearly understood although there are plenty of studies on this subject. There have been many reports ${ }^{1-6}$ ) that lipid plays an important role in the calcification of hard tissues. Irving ${ }^{1)}$ and Wuthier ${ }^{4}$ reported that lipid may be intimately concerned with the mineralization of bone and a considerable amount of data on the function of lipids in bone and epiphyseal cartilage has been made available. However, the metabolic relation between lipid and calcification process in bone and epiphyseal cartilage is still not clear.

Recently, Nagayama, et al. ${ }^{7)}$ reported that sudanophilia was closely involved in the mechanism of normal calcification in tooth, bone and epiphyseal cartilage of rats. However, these reports about sudanophilia and calcification concern tooth and only long bones such as the tibia. No one has reported the relation between lipid and calcification in the mandibular condyle of animals. Condylar cartilage of the mandible is anatomically different from epiphyseal cartilage of the long bone and it functions as both articular cartilage and epiphyseal cartilage ${ }^{8)}$.

The present study was undertaken to ascertain whether histochemical changes of sudanophilia in the mandibular condyle are similar to those in epiphyseal cartilage of the long bone, as part of a series of investigations on the mechanism of physiological calcification in bone.

\section{Materials and Methods}

Thirty male rats of the Wistar strain, 23 days old when the experiment was begun, were divided into four groups of 10 each as follows: a control group fed a well balanced optimal diet (control diet), a low calcium $(\mathrm{Ca})$ group given a control diet with $\mathrm{Ca}$ excluded (low $\mathrm{Ca}$ diet) and a strontium ( $\mathrm{Sr}$ ) group in which the added calcium in the control diet was replaced by strontium (Sr diet). Each group was given the respective diet mentioned above and deionized water ad libitum for 3 weeks. The composition of the diets is shown in Table $1^{9)}$. The body weight of rats in all groups was recorded daily to observe the influence of the diets on growth and development in the rats.

All rats were sacrificed by decapitation under ether anesthesia at the end of the experimental period. Both the left and right mandibles were dissected immediately, their adherent tissues were removed and then fixed in Baker's formol-calcium solution ${ }^{10)}$. According to Irving's method ${ }^{11)}$, they were placed in absolute alcohol at $60^{\circ} \mathrm{C}$ for 24 hours and then in benzol at $60^{\circ} \mathrm{C}$ for 24 hours, returned to absolute alcohol and washed in distilled water. Decalcification was carried out in 5\% nitric formol mixture and they were embedded in gelatin.

Longitudinal sections in the midfrontal plane, 10 to $15 \mu \mathrm{m}$ thickness, were cut using 
Table 1 Composition of diets

\begin{tabular}{|c|c|c|c|}
\hline & $\begin{array}{l}\text { Control } \\
\text { Diet (\%) }\end{array}$ & $\begin{array}{l}\text { Low } \mathrm{Ca} \\
\operatorname{Diet}(\%)\end{array}$ & $\begin{array}{c}\mathrm{Sr} \\
\operatorname{Diet}(\%)\end{array}$ \\
\hline Corn starch & 64.547 & 66.047 & 63.847 \\
\hline Casein from milk & 20.000 & 20.000 & 20.000 \\
\hline Cotton seed oil & 8.000 & 8.000 & 8.000 \\
\hline Vitamin mixture* & 1.000 & 1.000 & 1.000 \\
\hline \multicolumn{4}{|l|}{ Salts } \\
\hline $\mathrm{SrCO}_{3}$ & 0.000 & 0.000 & 2.200 \\
\hline $\mathrm{CaCO}_{3}$ & 1.500 & 0.000 & 0.000 \\
\hline $\mathrm{KCl}$ & 1.000 & 1.000 & 1.000 \\
\hline $\mathrm{NaHCO}_{3}$ & 0.700 & 0.700 & 0.700 \\
\hline $\mathrm{Fe}_{2}\left(\mathrm{SO}_{4}\right)_{2}\left(\mathrm{NH}_{4}\right)_{2} \mathrm{SO}_{4} \cdot 24 \mathrm{H}_{2} \mathrm{O}$ & 0.508 & 0.508 & 0.508 \\
\hline $\mathrm{KH}_{2} \mathrm{PO}_{4}$ & 1.700 & 1.700 & 1.700 \\
\hline $\mathrm{NaCl}$ & 0.500 & 0.500 & 0.500 \\
\hline $\mathrm{MgSO}_{4} \cdot 7 \mathrm{H}_{2} \mathrm{O}$ & 0.545 & 0.545 & 0.545 \\
\hline
\end{tabular}

* Salley and Bryson (1957)

a freezing microtome and then stained with a saturated solution of Sudan black B (Merck Co., Ltd., West Germany) dissolved in $70 \%$ alcohol and mounted in glycerin jelly.

\section{Results and Discussion}

In the control group, the intercellular area in the zone of provisional calcification was clearly stained with Sudan black B, and also the intracellular granules in the hypertrophic cells of the condylar cartilage were weakly stained with the dye. A large number of granules were also seen in the cells of the spongiosa.

In the low Ca group, the staining of the matrix around the hypertrophic cells adjacent to the spongiosa was weaker than that in the control group. Sudanophil granules were scarcely seen in the cartilage cells although they were observed weakly in the cells of the spongiosa. However, it was recognized that as a whole, sudanophilic reaction in the low $\mathrm{Ca}$ group was similar to that in the control group. This fact suggests that calcification in the mandibular condyle of the rats fed a low $\mathrm{Ca}$ diet go forward in a form of insufficiency.

In the $\mathrm{Sr}$ group, the zone of hypertrophic cells was extremely extended. Sudanophil material completely disappeared in the intercellular area corresponding to the zone of provisional calcification. However, weak sudanophilic reaction was seen in the area corresponding to spongiosa. It was also recognized that the appearance of sudanophil granules in the cells of spongiosa in the Sr group was different from those in the control and the low $\mathrm{Ca}$ groups. These phenomena indicate that in the $\mathrm{Sr}$ group, the normal system of endochondral ossification in condylar cartilage was strongly inhibited and that the tissue corresponding to spongiosa formed after administration of $\mathrm{Sr}$ carbonate was osteoid tissue. These findings in the low $\mathrm{Ca}$ and the $\mathrm{Sr}$ groups were similar to those in the epiphyseal cartilage of tibiae, as previously reported ${ }^{12)}$.

It is not clear why rachitic changes in the rats given the $\mathrm{Sr}$ diet were stronger than those in the rats given the low Ca diet. Some hypotheses $^{13,14)}$ have been presented to explain this phenomenon. Engfeldt et al. ${ }^{15)}$ proposed that the most likely hypothesis was the adverse effect of $\mathrm{Sr}$ on intestinal absorption on available $\mathrm{Ca}$. However, the true etiology is not clear and remains to be investigated.

As stated above, it is assumed that the appearance of sudanophilic reaction is intimately concerned with calcification process. 
These facts suggest that sudanophilia is closely involved in the mechanism of normal calcification and ossification in the condylar cartilage of mandible of the rat, being similar to that in tooth, bone and epiphyseal cartilage.

\section{References}

1) Irving, J. T.: Histochemical changes in the epiphyseal cartilage during rickets. Nature 183: 1734-1735, 1959.

2) Gruess, R. L. and Clark, I.: Alterations in the lipids of bone caused by hypervitaminosis A and D. Biochem. J. 96: 262-265, 1965.

3) Shapiro, I. M., Wuthier, R. E. and Irving, J. T.: A study of the phospholipids of bovine dental tissues-I Enamel matrix and dentine. Archs. Oral Biol. 11: 501-512, 1966.

4) Wuthier, R. H.: Lipids of mineralizing epiphyseal tissues in the bovine fetus. J. Lipid Res. 9: 68-78, 1968

5) Havivi, E. and Bernstein, D. S.: Lipid metabolism in normal and rachitic rat epiphyseal cartilage. Proc. Soc. Exptl. Biol. Med. 131: 1300-1304, 1969.

6) Wolinsky, I. and Guggenheim, K.: Lipid metabolism of chick epiphyseal bone and cartilage. Calcif. Tiss. Res. 6: 113-119, 1970.

7) Nagayama, M., Saburi, N., Oka, T., Yamada, S. and Matsumoto, A.: Sudanophilia at the sites of calcification in hard tissues of rats given strontium carbonate. Jpn. J. Oral Biol. (in press), 1984.

8) Morita, S., Hanada, K. and Ozawa, H.: Ultrastructure and cytochemistry of acid phosphatase activity in the condylar cartilage of the young rat mandible. Bone Metabolism 14: 244-251, 1981. (in Japanese)

9) Salley, J. J. and Bryson, W. F.: Vitamin A deficiency in the hamster. J. Dent. Res. 36: 935-944, 1957.

10) Baker, J. R.: The histochemical recognition of lipine. Quart. J. Micr. Sci. 87: 441-470, 1946.

11) Irving, J. T.: Histochemical changes in the early stages of calcification. Clin. Orthop. 17: 92-101, 1960.

12) Matsumoto, A.: Sudanophil material at the sites of calcification in dentine, bone and epiphyseal cartilage plate in the rat given strontium carbonate. Tsurumi Univ. Dent. J. 1: 21-28, 1975.

13) Sobel, A. E., Nobel, S. and Hanok, A.: The reversible inactivation of calcification in vitro. Proc. Soc. Exptl. Biol. Med. 72: 68-72, 1949.

14) Johnson, A. R.: Strontium, calcium, magnesium and phosphorus content of rat insisors as determined by electron microprobe analysis. J. Dent. Res. 51 : 115-121, 1972.

15) Engfeldr, B., Hjertquist, S-O. and Lagergren, C.: The effect of strontium intake on rats maintained on a very low calcium diet. Acta Soc. Med. Uppsal. 67: 239-257, 1962.

\section{Explanation of figures}

Fig. 1 Control group: Note the clear sudanophil material (arrow) in the matrix around the hypertrophic cells adjacent to the spongiosa.

Fig. 2 Higher magnification of Fig. 1: Sudanophilic reaction was also seen in the hypertrophic cells and the cells of the spongiosa (arrows).

Fig. 3 Low Ca group: Sudanophilic reaction in the intercellular area in the lower part of the hypertrophic cells adjacent to the spongiosa (arrows) was weaker than that in the control group.

Fig. 4 Higher magnification of Fig. 3: The sudanophil granules were scarcely seen in the hypertrophic cells. Note the sudanophilia (arrows) in the zone of provisional calcification.

Fig. $5 \mathrm{Sr}$ group: Sudanophil material completely disappeared in the intercellular area in the lower part of the hypertrophic cells adjacent to the area corresponding to spongiosa.

Fig. 6 Higher magnification of Fig. 5: Note complete absence of sudanophil material in the matrix around the hypertrophic cells (arrow).

HC: hypertrophic ells, S: spongiosa, Os: osteoid tissue, ZPC: zone of provisional calcification, $\mathrm{m}$ : medial side, $\mathrm{l}$ : lateral side. 


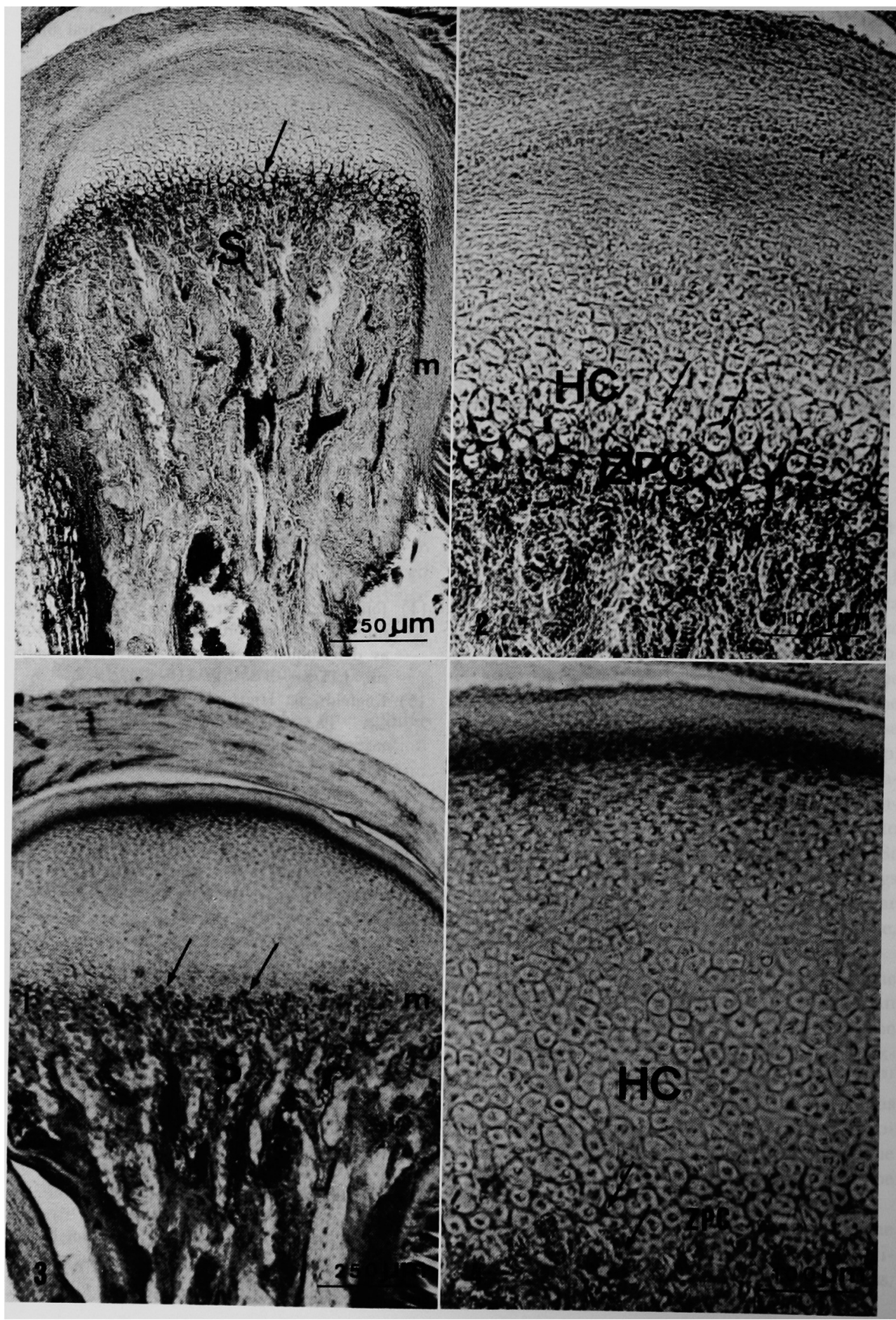




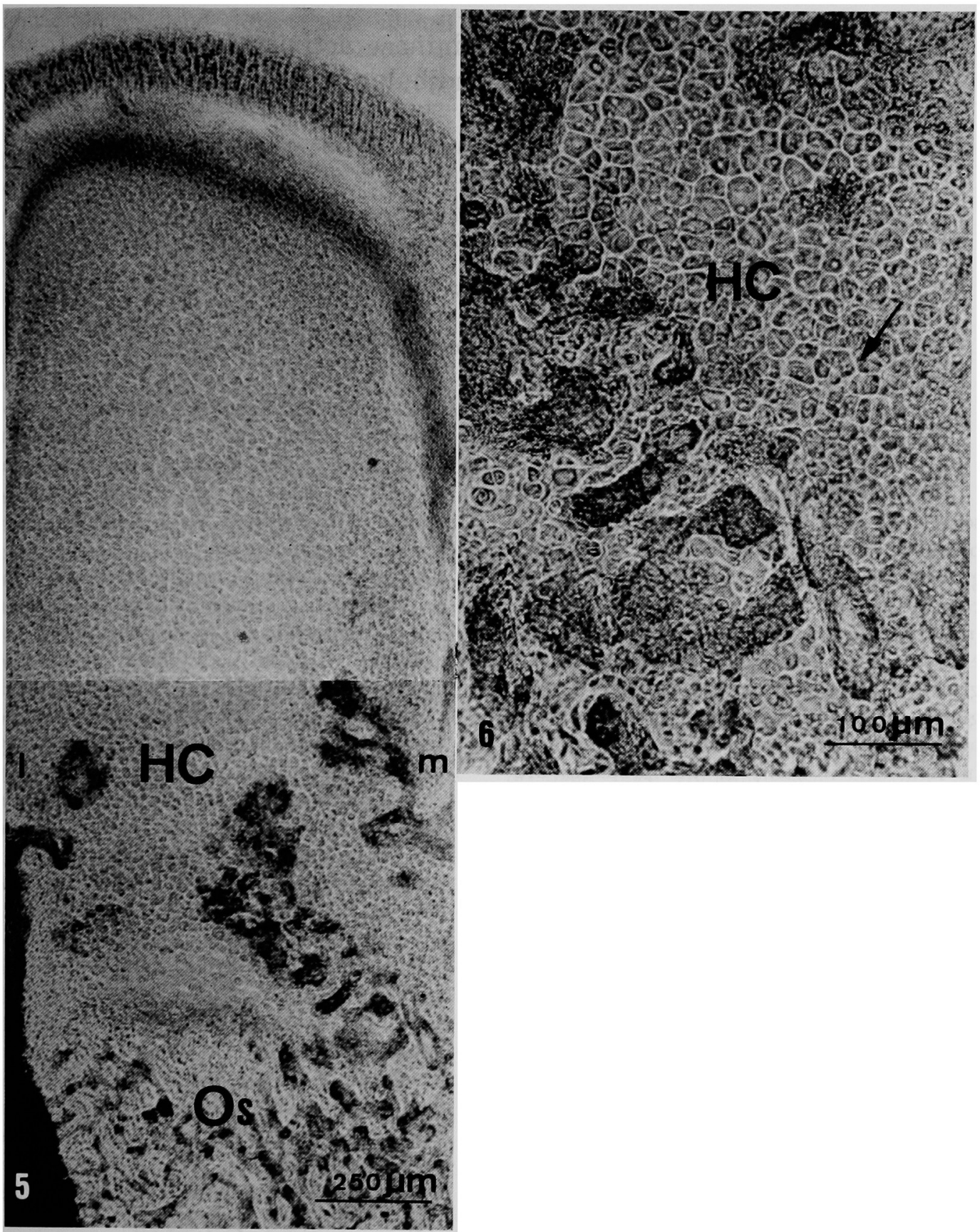

